\title{
A PLASMA FIBRINOGEN-INCREASING FACTOR OBTAINED FROM STERILE ABSCESSES IN DOGS ${ }^{1}$
}

\author{
BY F. HOMBURGER 2 \\ (From the Laboratory of Pathology, Yale University School of Medicine, New Haven)
}

(Received for publication April 28, 1944)

\section{Introduction}

The systemic changes resulting from localized inflammation have been the subject of many studies. The possible mechanisms producing fever have been reviewed by Barbour (1), and recently the mechanisms of the production of fever with inflammation were investigated by Menkin $(2,3)$ who has also studied the causative factors of leukocytosis (4). Changes occurring in the plasma protein during inflammation are well recognized and it has been repeatedly found that parenteral injection of foreign proteins causes a slow progressive increase of plasma fibrinogen, lasting for several days (5 to 8 ). The liberation of protein split products in inflammatory foci like turpentine abscesses has been blamed as furnishing material from which an excess of plasma proteins would be formed (9). Such a hypothesis, however, falls short of explaining why the fibrinogen fraction should be electively affected, as was shown in experimental studies and in clinical investigation (10).

The present study is concerned with the effects, in healthy dogs, of the injection of sterile purulent material obtained from turpentine abscesses in donor dogs. The plasma fibrinogen level, total plasma proteins, hematocrit values, the white blood cell count, and the temperature of the recipient dogs were observed. An attempt was made to fractionate the purulent material into the components responsible for the different changes observed. ${ }^{3}$

This report deals with the effects of such substances upon the recipient's plasma fibrinogen concentration.

\footnotetext{
1 This work was aided by a grant from the Commonwealth Fund.

2 Present address, 818 Harrison Ave., Boston.

- This part of the problem was suggested by Dr. E. Mylon and the work begun under his supervision.
}

\section{Methods \\ A. Animals and criteria for normality}

Twenty-one adult mongrel dogs of both sexes were used; 4 served as donor dogs, and 17 as recipients. The following 6 criteria for normality were applied to both recipient and donor dogs.

(1) Healthy and alert appearance.

(2) Plasma fibrinogen levels between 250 and $450 \mathrm{mgm}$. per $100 \mathrm{ml}$. of plasma.

(3) Upper limit of leukocyte count 12,000 cells per c.mm.

(4) Hematocrit value 35 to 45 per cent.

(5) Total plasma proteins 4.5 to 6.5 grams per $100 \mathrm{ml}$. of plasma.

(6) Rectal temperature 100.5 to $103^{\circ} \mathrm{F}$. (The upper limit of the normal temperature as observed in resting animals (11) is $101^{\circ} \mathrm{F}$. The higher temperatures observed in some of the dogs in this series before any injection probably were due to excitement, struggling, and muzzling.)

\section{B. Preparation of the crude material and fractionation}

One and a half to $2 \mathrm{ml}$. of commercially rectified oil of turpentine (USP) were injected into the gluteus muscle of each of 4 dogs. Within 3 to 5 days, an abscess formed at the site of injection and became fluctuant. Puncture with a No. 12 gauge needle under sterile precautions yielded from 20 to $150 \mathrm{ml}$. of creamy yellow to pink pus. This was cultured to establish its sterility, diluted with equal volumes of 0.85 per cent sodium chloride solution, frozen for 24 hours, thawed, and then centrifuged. Three distinct layers were obtained. The uppermost was white and greasy and microscopically contained white blood cells and fat droplets. The middle and largest layer consisted of a red to pink fluid with amorphous debris and some red blood cells. At the bottom of the centrifuge tube, there was a small portion of muscular debris, fibrin, and red blood cells. The middle and largest portion was chosen for these experiments and preserved by freezing. The properties of the top and bottom layers were not investigated.

About 24 hours following the treatment described above, the pus mixture was thawed and parts of it filtered through dressing gauze (Fraction $A$ ), Whatman filter paper number 40 (Fraction $B$ ), and Berkfeld filters type V (Fraction $C$ ). Fraction $D$, which contained $7 \mathrm{mgm}$. of protein per $100 \mathrm{ml}$., was obtained by heating portions of Fraction $\mathbf{C}$ for 24 hours at $60^{\circ} \mathrm{C}$. Fraction $E$ was obtained by heating parts of Fraction $\mathrm{C}$ for 24 hours at $75^{\circ} \mathrm{C}$. The resulting precipitate was eliminated by centrifugation. Fraction $F$ was ob- 
tained by the addition of acetic acid to portions of fraction C until pH 4.4 was reached. This caused a precipitate which was centrifuged and redissolved in sodium hydroxide and sodium bicarbonate at $\mathrm{pH}$ 8.6. Fraction $G$. The supernatant fluid remaining after acidification of portions of Fraction $\mathrm{C}$ was brought to $\mathrm{pH} 7.1$ by the addition of sodium hydroxide. Portions of this fraction were examined by the addition of ammonium sulphate in concentrations of 33 per cent, 50 per cent, and at saturation. At each of these additions, an appreciable precipitate formed.

\section{Experimental}

Each dog used as a recipient in these experiments received only one injection of one fraction. These were given intramuscularly to dogs 4 and 5 and intravenously to all other animals. When the intravenous route was used, care was taken to give the injections slowly in order to avoid unrelated systemic reactions. The doses administered varied from $0.55 \mathrm{ml}$. to $1.9 \mathrm{ml}$. of filtrate per lb. (453.6 grams) of body weight.

Following the injections, blood samples were taken at 3-hour intervals during the first 24 hours, at 36 hours, and sometimes at 48 hours after the injections. Rectal temperatures were taken at the same time intervals. Blood from leg veins was used for the determination of the plasma fibrinogen, total protein, and hematocrit values. Total proteins were determined by the Kjeldahl semi-micromethod on $0.1 \mathrm{ml}$. of plasma.

Determinations of the plasma fibrinogen were done according to the method described by Mylon et al. (12). By this method, the fibrinogen content of a precipitate formed by the addition of protamine sulfate to diluted plasma is determined. According to the authors of the method this precipitate can be redissolved in 3 per cent saline and "the resulting solution coagulates between 54 and $56^{\circ}$ and becomes gelatinous in consistency several hours after addition of fresh serum (thrombin). These characteristics identify this substance as fibrinogen, as far as this is possible." The authors of this method also state that it does not yield higher values due to the protamine contained in the precipitate. The final $\mathrm{N}_{2}$ determinations were done in the usual way after addition to the precipitate of cupric sulfate and sulfuric acid and following digestion.

Control experiments were done on 3 dogs by intravenous injection of dog plasma which had been incubated under sterile conditions in the presence of turpentine for $\mathbf{5}$ days. Such injections failed to cause any changes of the blood proteins.

\section{Results}

The results of the injections of the different fractions of sterile pus are summarized in Table I.

Fraction $A$ was injected intramuscularly into dogs 4 and 5 and caused an increase of the plasma fibrinogen concentration which reached its peak 20 and 14 hours later. At autopsy, no
TABLE I

Effects of injection of various fractions of sterile pus from turpentine abscesses

\begin{tabular}{|c|c|c|c|c|}
\hline $\begin{array}{l}\text { No. of receiver dog and } \\
\text { route of injection }\end{array}$ & $\begin{array}{c}\text { Amount } \\
\text { injected }\end{array}$ & $\begin{array}{c}\text { Initial } \\
\text { fibrino- } \\
\text { gen }\end{array}$ & \multicolumn{2}{|c|}{$\begin{array}{l}\text { Rise in fibrinogen } \\
\text { in percentage of } \\
\text { initial level. } \\
\text { Time of peak }\end{array}$} \\
\hline \multicolumn{5}{|c|}{ (Fraction A) } \\
\hline $\begin{array}{l}4 \text { i.m. } \\
5 \text { i.m. } \\
6 \text { i.v. } \\
8 \text { i.v. } \\
12 \text { i.v. (second rise) } \\
12 \text { i.v. (first rise) }\end{array}$ & \begin{tabular}{|c|}
$m l$. per $l b$. \\
of wt. \\
0.55 \\
0.58 \\
0.68 \\
1.00 \\
1.60
\end{tabular} & $\begin{array}{c}\text { mgm. } \\
\text { per } \\
100 \mathrm{ml} . \\
450 \\
410 \\
437 \\
428 \\
472\end{array}$ & $\begin{array}{l}\text { per cent } \\
40 \\
31.7 \\
71.86 \\
89.58 \\
48.78 \\
24.40\end{array}$ & $\begin{array}{c}\text { hours } \\
20 \\
14 \\
6 \\
10 \\
24 \\
9\end{array}$ \\
\hline
\end{tabular}

(Fraction $\mathrm{B}$ )

\begin{tabular}{r|r|r|r|r}
\hline 9 i.v. & 0.75 & 358 & 68.43 & 26 \\
\hline \multicolumn{5}{c}{ (Fraction C) } \\
\hline 13 i.v. & 0.75 & 367 & 71.70 & 24 \\
15 i.v. & 1.60 & 437 & 26.40 & 12 \\
17 i.v. & 1.00 & 315 & 29.41 & 6 \\
18 i.v. & 1.10 & 390 & 54.60 & 13 \\
\hline
\end{tabular}

(Fraction D)

\begin{tabular}{l|l|l|l|l}
\hline 19 i.v. & 1.36 & 350 & 29 & 9 \\
\hline
\end{tabular}

(Fraction E)

\begin{tabular}{l|l|l|l|l}
\hline 22 i.v. & 1.00 & 444 & 00 & \\
\hline
\end{tabular}

(Fraction F)

\begin{tabular}{l|c|c|c|c}
\hline 21 i.v. & 1.3 & 428 & 37.7 & 3 \\
\hline \multicolumn{6}{c}{ (Fraction G) } \\
\hline 27 i.v. & 1.9 & 400 & 00 & \\
\hline
\end{tabular}

local reaction was found at the site of injection which per se could have accounted for the increase in fibrinogen. Fraction $A$ was injected intravenously into dogs 6,8 , and 12 . In these dogs, the fibrinogen increase began between the 2nd and 12th hours following injection and reached peaks in from 6 to 24 hours. The fibrinogen response to the intravenous injection of Fraction $B$ (filtered through the filter paper) in dog 9 was similar in its intensity and course. Fraction $C$ (filtered through Berkfeld filters type V) was injected intravenously into dogs 13,15 , 
17, and 18. All except dog 13 showed rapid increases of plasma fibrinogen which reached peaks in from 6 to 13 hours.

Dogs 12 and 13, the first receiving Fraction A and the second receiving Fraction $\mathrm{C}$, responded in a different way, with the fibrinogen concentration dropping back to the initial level following a first rise and preceding a second, more marked increase. Coincident with this second rise, there was a fall in the number of leukocytes and, in $\operatorname{dog} 12$, an increase in the total proteins. The general reactions of these 2 animals were different from those seen in all others. Whereas in general there was no manifest systemic reaction or merely drowsiness, dogs 12 and 13 were prostrated and sick. Indeed, dog 13 even vomited after injection.

Fraction $D$ (heated for 24 hours at $60^{\circ} \mathrm{C}$.) was injected intravenously into dog 19 and caused a fibrinogen increase of 29 per cent in 9 hours. Fraction $E$ (heated for 24 hours at $75^{\circ} \mathrm{C}$.) failed to cause any appreciable changes in plasma fibrinogen in dog 22 after intravenous injection. Fraction $F$ (reneutralized precipitate) obtained at $\mathrm{pH} 4.4$ caused, after intravenous injection, a fibrinogen increase of 37 per cent of the initial level in 9 hours. Fraction $G$ (reneutralized supernatant fluid) failed to cause any fibrinogen increase.

None of the injected fractions caused any appreciable changes of the total plasma proteins or of the hematocrit values except in $\operatorname{dog} 12$ as mentioned above.

\section{Discussion}

From the observations reported, it became apparent that pus obtained from sterile turpentine abscesses contains a substance which when injected intravenously or intramuscularly into normal dogs will increase the plasma fibrinogen level. The fibrinogen increase following its injection is more rapid and more considerable than the fibrinogen response observed by earlier workers (5 to 8), following parenteral injection of foreign proteins. Filtration through Berkfeld filters does not change the activity of the substance. The fibrinogen-increasing activity is impaired by heating to $60^{\circ}$ and abolished by heating to $75^{\circ}$ for 24 hours. All of the active substance is precipitated at $\mathrm{pH} 4.4$, indicating a relation to protein. The protein of the supernatant fluid, however, has no fibrinogen-increasing activity.

The liberation of such plasma fibrinogenincreasing substances at the site of inflammation may be responsible for the plasma fibrinogen response to noxious stimuli.

\section{Conclusions and summary}

Sterile pus obtained from turpentine abscesses and diluted with equal amounts of saline causes an increase in plasma fibrinogen concentration when injected into the veins or muscles of normal dogs. The active substance can pass through a Berkfeld filter and is thermolabile. A precipitate obtained from the Berkfeld filtrate at $\mathrm{pH} 4.4$ contains all of the active material.

\section{BIBLIOGRAPHY}

1. Barbour, H. G., The heat regulating mechanism of the body. Physiol. Rev., 1921, 1, 295.

2. Menkin, V., On the mechanism of fever production with inflammation. Proc. Soc. Exper. Biol. and Med., 1943, 54, 184.

3. Menkin, V., Chemical basis of fever. Science, 1944, $100,337$.

4. Menkin, V., The Dynamics of Inflammation. Macmillan, New York, 1940.

5. Henlein, H., Das Verhalten der Bluteiweisskörper bei parenteraler Zufuhr von Eiweiss und Nichteiweisskolloiden. Arch. f. exper. Path. u. Pharmakol., 1935, 179, 127.

6. Berger, W., Uber die Hyperproteinemie nach Eiweissinjektionen. Ein Beitrag zur Pathologie des Serumproteins und zur Proteinkörpertherapie. Klin. Wchnschr., 1922, 1, 1053

7. Frisch, A., and Starlinger, W., Chemisch-physikalische Blutuntersuchungen zur Frage der Protoplasmaaktivierung. Ztschr. f. d. ges. exper. Med., 1921, 24, 142.

8. Von den Velden, R., Die Blutgerinnung nach parenteraler Zufuhr von Eiweisskörpern. Deutsches Arch. f. klin. Med., 1914, 41, 298.

9. Madden, S. C., Finch, C. A., Swalbach, W. G., and Whipple, G. H., Blood plasma protein production and utilization; influence of amino acids and of sterile abscesses. J. Exper. Med., 1940, 71, 283.

10. Ham, T. H., and Curtis, F. C., Plasma fibrinogen response in man. Medicine, 1938, 17, 413.

11. DeBeer, E. J., and Hjort, A. M., An analysis of the basal metabolism, body temperature, pulse rate and respiratory rate of a group of pure bred dogs. Am. J. Physiol., 1938, 124, 517.

12. Mylon, E., Winternitz, M. C., de Sütö-Nagy, G. J., The determination of fibrinogen with protamine. J. Biol. Chem., 1942, 143, 21. 